\title{
Mosaic as an Element of the Synthesis of Architecture and Monumental Art in the Architecture of Volgograd and Volzhsky
}

\author{
Valentina Serebryanaya ${ }^{1, *}$ Irina Shevchuk ${ }^{1, a}$ \\ ${ }^{1}$ Institute of Architecture and Civil Engineering, Volgograd State Technical University, Volgograd, Russia \\ ${ }^{a}$ Email: iria.shevchuck@yandex.ru \\ *Corresponding author. Email: val38@mail.ru
}

\begin{abstract}
The article examines all the existing and lost mosaics displayed on public and residential buildings in the territory of Volgograd and Volzhsky. The issues of typology and stylistics of mosaics are also examined. The classification of the features of mosaic compositions has been carried out. The author makes an attempt to summarize and scientifically comprehend the creative work of Volgograd monumental artists. The article is supported by archival and exterior photographs.
\end{abstract}

Keywords: Volgograd, Volzhsky, Synthesis, Monumental art, Mosaic, Architecture.

\section{INTRODUCTION}

The urban environment is a complex functionalspatial system of inseparably linked parts of the city such as buildings and structures, as well as the space of streets, crossroads and squares. It must be organized in the way to satisfy basic needs of a person. To achieve this, it is necessary for each part of the city to have a certain semantic load created by various components.

A well-known Russian scientist D.S. Likhachev wrote about the importance of urban environment in "The Notes about Russian": "Streets, squares, canals, houses, parks remind, remind, remind ... Impressions of the past enter the spiritual world of a person unobtrusively and non-persistently, and a person with an open soul enters the past. ... And then the past and the future become inseparable for him, because each generation is like a connecting link in time." [1].

The concept of urban environment is becoming a key one, necessary in creating a convergence of architecture with the expectations and preferences of people living in the city. Therefore, architects not only design the functional purpose of buildings, but they also form a certain emotional, cultural and informational content. To do this, they use various shapes and proportions; constructive schemes; coloristic, compositional and decorative solutions.

Such decorative solution as mosaic panels on the facades of buildings is of particular interest. Mosaics do not have a protection status, so they are hidden with impunity behind new buildings and structures, destroyed while repairing facades, disfigured being unprofessionally and often uncoordinatedly reconstructed. That is the reason why this problem is of special importance.

The aim of the research is to analyze mosaics using the examples of the facades of public and residential buildings in Volgograd and Volzhsky.

According to this aim, the main objectives of the study were:

- $\quad$ identifying mosaics of cities;

- studying the history of mosaics development in Volgograd and Volzhsky;

- describing the basic principles of the spatial arrangement of mosaics;

- establishing the regional features of monumental painting of Volgograd and Volzhsky facades;

- $\quad$ determining the place of mosaic in creating a holistic urban environment. 
The study of scientific papers showed that today there are no special publications on the selected topic. In the books of V.I. Atopov, V.E. Maslyaev, A.F. Lipyavkin [2] and P.P. Oleinikov [3], the emphasis is solely made on the architecture of Volgograd.

In art history the problems of the synthesis of arts are considered by such researchers as S.S. Valerius, V.P. Tolstoy, O. A. Shvidkovsky, E. B. Murina and others.

S.S. Valerius in his work "Monumental Painting. Contemporary problems" [4] reveals the main problems and tendencies of monumental painting. The art critic studies the relationship of art and architecture and determines the role of their synthesis in urban planning.

In the book "Soviet monumental painting" [5] V.P. Tolstoy gives a clear definition of monumental painting, which can exactly correspond to any monumental work and to monumental art in general.

O.A. Shvidkovsky in his work "Harmony of Interaction: Architecture and Monumental Art" [6] traces the principles on which arts cooperating is based on. The author pays special attention to assessing the role of architectural monuments in forming modern ensembles.

In the work "Problems of the synthesis of spatial arts" [7] E.B. Murina presents the scientific analysis of the theory and practice of the synthesis of arts - architecture, sculpture and painting. The art critic believes that the interest in the synthesis of arts is associated with attempts to save traditional values of world culture from the destructive offensive of civilization.

However, the subject of research made by art critic was the monumental painting of artists from Moscow, Leningrad, the centers of the Soviet republics, as well as artists from the West and Mexico.

The works devoted to the study of urban [8] and public [9] spaces were also considered.

All of the above scientific works and papers have become the methodological basis of the article.

The scientific novelty of the research is that this work is the first attempt to generalize and scientifically understand the work of Volgograd monumental artists. The article is accompanied with the illustrations from the album "Volgograd Artist" [10], [11] of the Volgograd Union of Artists of Russia, images from electronic resources, as well as photographs of the authors and I.A. Bondarev.

\section{REVIEW: MOSAIC IN THE HISTORICAL CONTEXT OF THE URBAN ENVIRONMENT OF VOLGOGRAD AND VOLZHSKY}

Mosaics in the urban environment of Volgograd and Volzhsky are considered in a historical retrospective allowing us to analyze their formation as an element of the synthesis of architecture and monumental art.

Based on the field studies of Volgograd and Volzhsky authors of architecture, it can be concluded that mosaic panels in these cities developed in the 60 s of the XX century for a number of reasons.

The first of them is the plan of "monumental propaganda" [12] put forward by V.I. Lenin in 1918. According to this plan, the main goal of monumental art and architecture was to influence the ideological and artistic education of a person and satisfy his spiritual and aesthetic needs.

The next reason is the ideological significance of the city. Stalingrad (now Volgograd) is a symbol of the valor and stamina of the Soviet people during the Great Patriotic War. It was supposed to become the capital of victory, which justified close attention to the way the city looks.

The decree of the Central Committee of the CPSU from November 4, 1955 "On the elimination of excesses in design and construction" [13], which rejected individual projects with decorative elements: porticoes, colonnades, pilasters, complex cornices, moldings and others, also had a great influence. The architects faced the problem of aesthetic poverty and plastic monotony of architecture. The facades were flat, faceless, devoid of articulations and the play of light and shade. Therefore, there was a need for decorative and monumental solutions. Monumental painting began to be widely included in architectural structures, and first all in public buildings: theaters, houses of culture, train stations, as well as in industrial buildings. Mosaics became an integral part of city design. The work of monumental artists became prestigious.

Finally, in the second half of the 1950s, a group of bright young monumental artists, graduates of the Stroganov and Mukhinsky schools, arrived in Volgograd. It should be added that the turn of the 
50-60s became a new stage in Soviet art development. New solutions were suggested by young artists called the "sixties". Their works rejected naturalism, academicism and strove to a generalized-figurative embodiment, bringing the monumental art of Volgograd and Volzhsky closer to the high artistic level of capitals.

In 1961 a group of Volgograd artists: N.F. Barokha, Yu.I. Bosco, A.V. Golovanov, P.L. Malkov, M. Ya. Pyshta - received a competitive order for decorating the overpass of the Volzhsky hydroelectric station. The panel of $14 \times 45$ meters got the name "Energy to People" and was later fragmentarily repeated in Moscow on the facade of the building in Bolshaya Polyanka Street 60/2. It should be mentioned that the work combines two techniques at once - mosaics and relief, which will become one of the characteristic features of the monumental painting of Volgograd and Volzhsky ("Figure 1"). Another work is a mosaic diptych in Engels Street in Volzhsky, which was made by N.F. Barokha in 1966. The same combination as in the panel "Energy to People" was used here.

Mosaic diptychs made by N.F. Barokha is perceived and developed by many Volgograd monumental artists, which allows us to consider diptychs as a regional feature ("Figure 2").

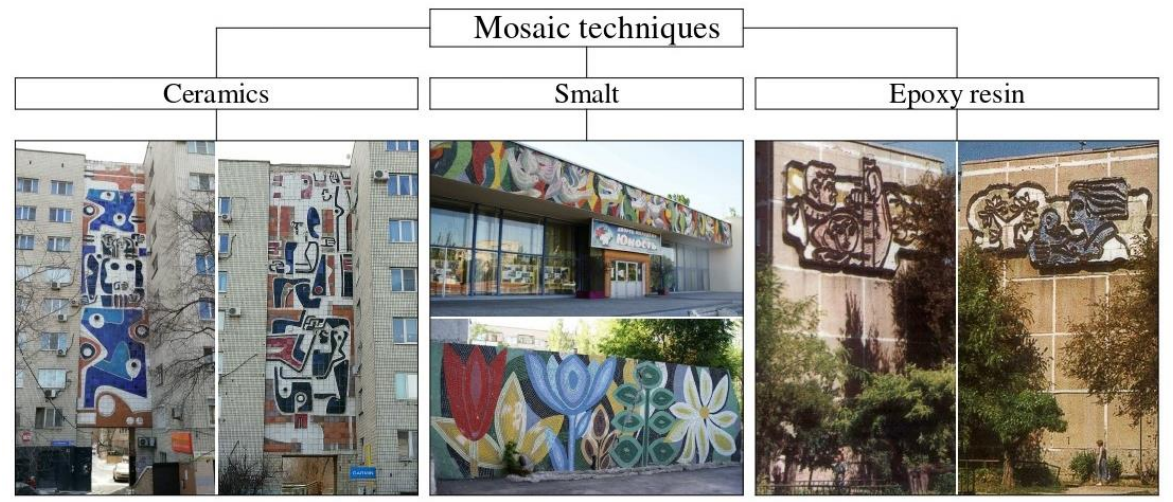

Figure 1 Mosaic techniques.

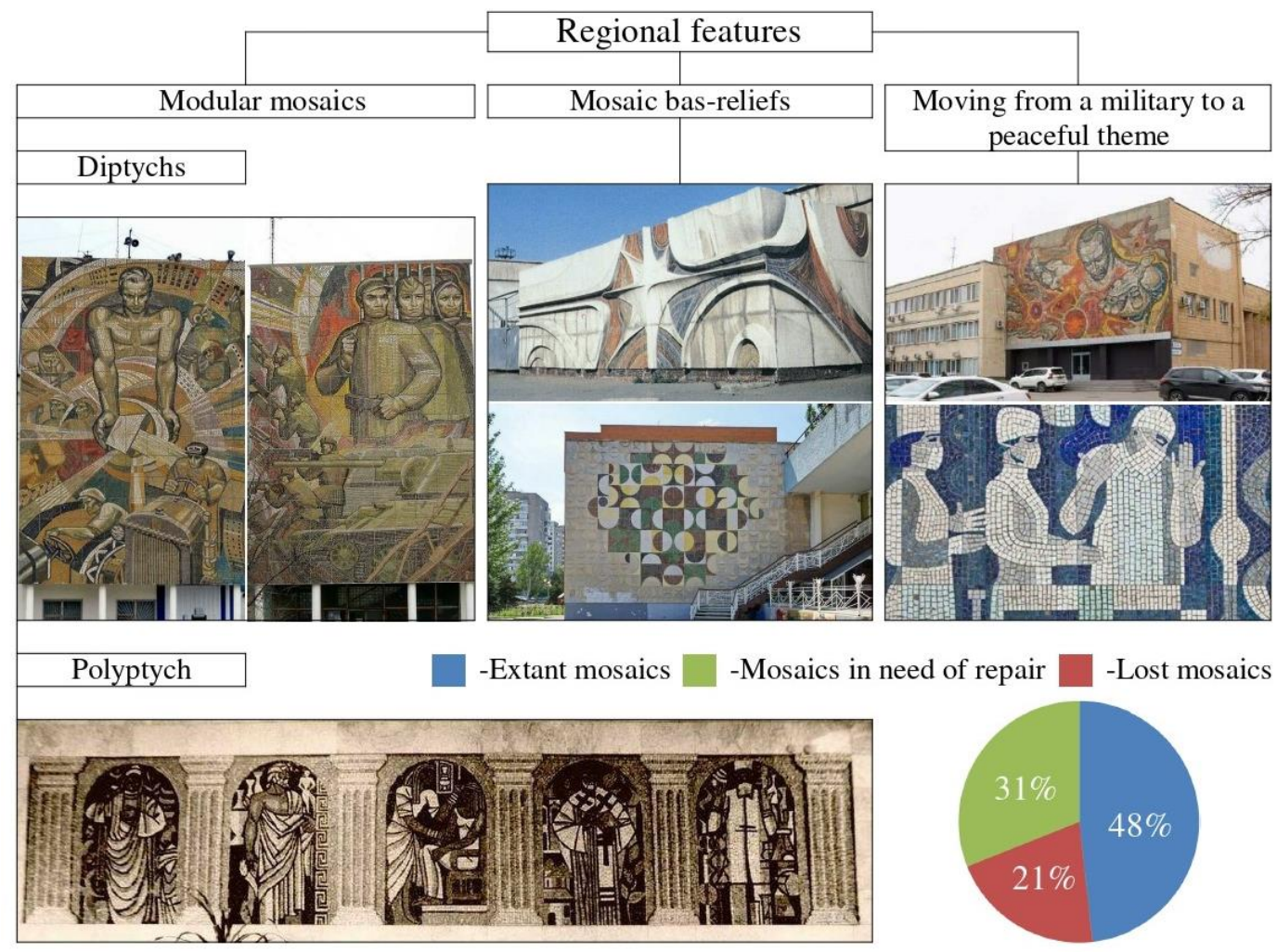

Figure 2 Regional features. 


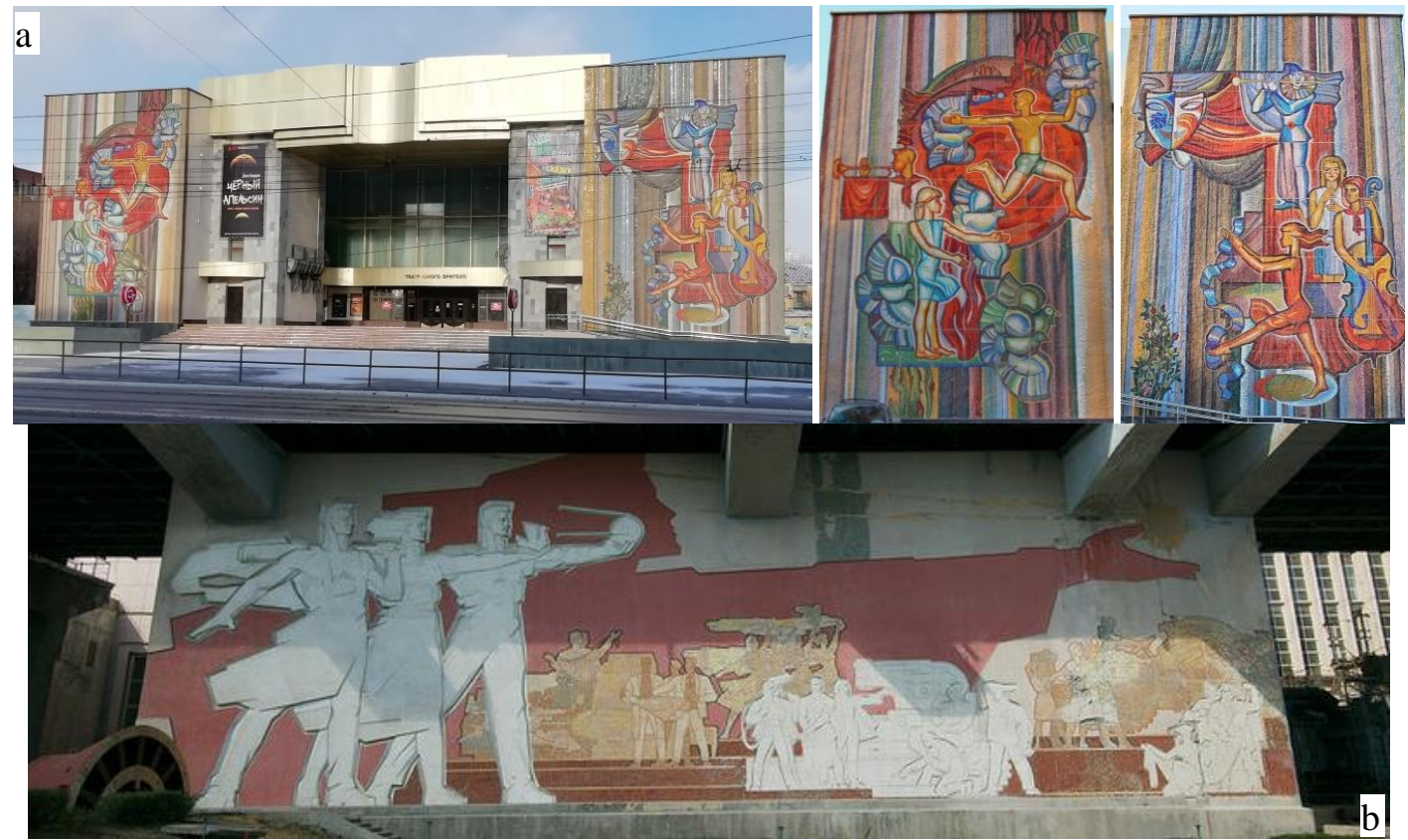

Figure 3 a. diptych of the Theater of the Young Spectator, 1968, authors: A.G. Brovko, V.G. Lee; b. "Energy to the People", 1961, authors: N.F. Barokha, Yu.I. Bosco, A.V. Golovanov, P.L. Malkov, M.Ya. Pyshta.

The example is mosaic diptych on the facade of the Theater for Young Spectators by artists A.G. Brovko and V.G. Lee (1968). The diptych, located on two side projections, decorates the entrance group of the building. Actors and musicians of the theater are depicted to the right of the entrance, and their audience to the left, so that to emphasize the functional purpose of the building. The vertical stripes, which appeared after reconstructing the theater, have a rhythmic character and emphasize the vertical development of the facade ("Figure 3").

In the 70 s the constant systematic filling of the urban environment with sculptural monuments and compositions on a military-historical theme led to creating an uncomfortable environment in the city. It was during this period that the predominant orientation of the artistic thinking of the monumentalists was aimed at finding new plastic solutions and themes that would symbolize peace and cooperation. In this regard, the sculpture moved into the background, giving way to mosaics. The main themes of monumental painting were science and astronautics which were rapidly developing at that time.

The masters moved away from the narrative of socialist realism, preferring artistic and philosophical images of abstractionism, which is characterized by temperament, dynamism, a high degree of generalization, decorative transformation of motives and active work with color in local, extensive planes. It can be explained by the wide coverage of the work of foreign monumentalists such as Siqueiros [14], Leger [15], Rivera, Orozco and others.

Here appears the desire to use monumental art not only on public buildings, but also on residential buildings. An example is the mosaics of V.G. Kurochkin "The Conquest of Fire" and "The Conquest of Water" (1971-1974) at 18A Nevskaya Street, which form a diptych. It is interesting that if earlier the panels of the diptych were closely linked to each other and united by one color palette, this diptych, as the work of P.F. Shardakov at the Volgograd Tractor Plant, focuses on contrast concepts such as fire and water, life and death, happiness and sadness, and so on. This contrast is also colorfully maintained.

From the late 70s - early 1980s Volgograd is becoming one of the largest tourist centers in the country. The number of tourists began to expand not only at the expense of the residents of the country, but also foreigners, which made monumental artists pay attention to the way the city looks, what impression it makes on visitors. A bright example is the ensemble that decorates the Volgograd tourist station. It consists of mosaic basreliefs "Peace to you" and "Rose of the Winds" (1975), to which the mosaic "Stalingrad - Hero City" (1984) was later added. All mosaics were made by the famous Volgograd monumental artist M.Ya. Pyshta ("Figure 4"). 

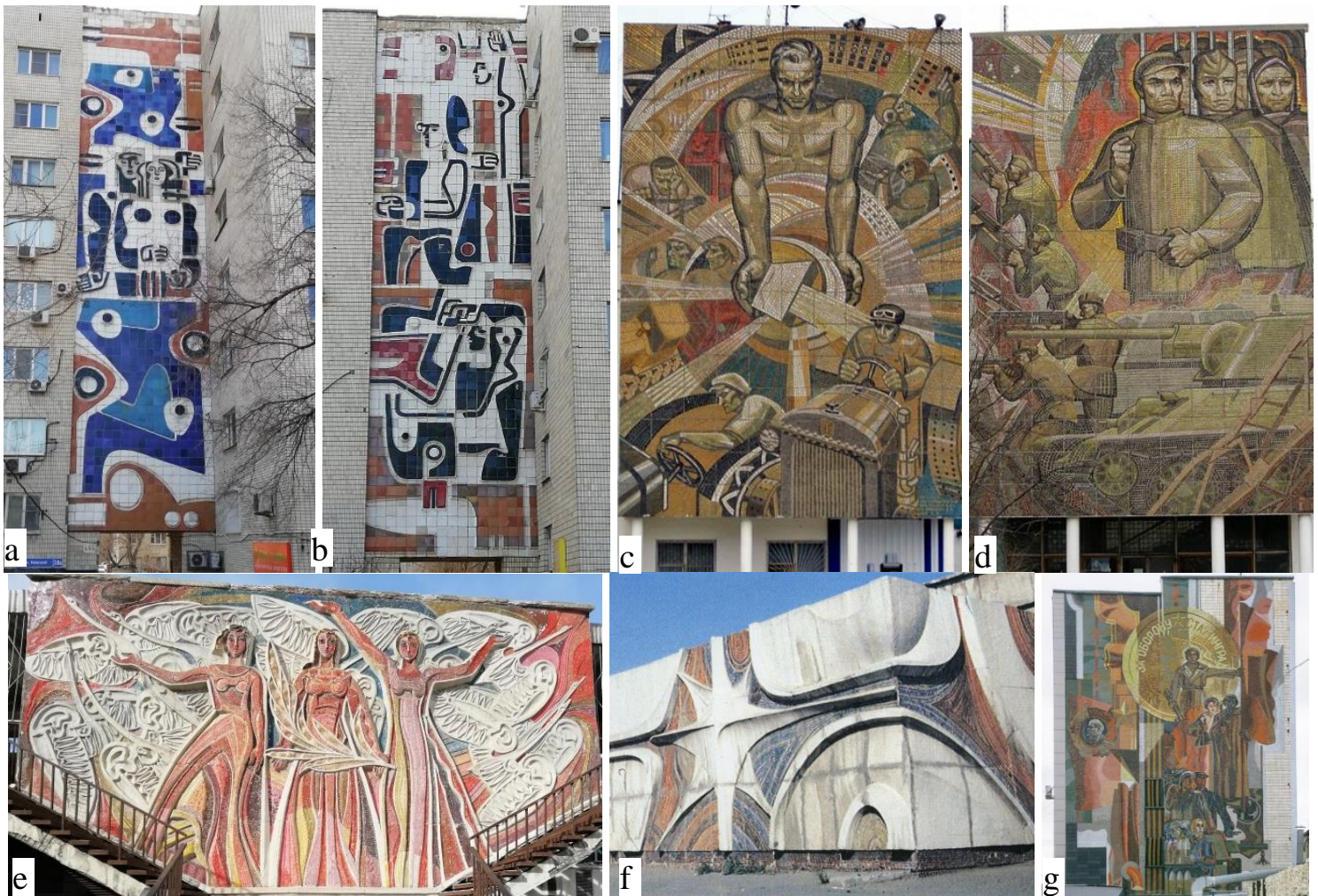

Figure 4 a. " The Conquest of water", b. " The Conquest of Fire", 1971-1974, author V.G. Kurochkin; c.

"Factory-worker", d. "Soldier Factory", 1973-1980, author P.F. Shardakov; e. "Peace to you", 1975, f. "Rose of Wind", 1975, g. "Stalingrad is a hero city", 1984, author M.Ya. Pyshta.

In the $80 \mathrm{~s}$ and $90 \mathrm{~s}$, instead of vertical, mosaics started to be horizontally developed. They were mainly located on the buildings of cinemas and houses of culture popular with the residents of the city. Particular attention was paid to placing monumental painting on educational institutions.

Therefore, fabulous animalistic and plant themes were reflected in mosaics.

Monumental painting is gradually moving from the urban environment of Volgograd to the interiors of public buildings, and later to the underground crossings.

During this period forming the artistic appearance of the Volzhsky city is observed which is associated, first of all, with the work of G.V. Chernoskutov. He created a number of reliefs, mosaics, frescoes that decorate the station, the palace of culture, libraries, cinemas, schools and hospitals in the city. The artist's works are distinguished by synthetic work with color, shape and material, expressive figurative solution, organic unity with the surrounding architectural environment.
The artist often refers to the image of the dove as a symbol of peace, inspired by the drawings of Pablo Picasso. This is most clearly expressed in the work "Doves" above the entrance to the cinema "Youth".

G.V. Chernoskutov developed diptychs to polyptychs and used modular mosaics to fully reveal the intended themes. An example is the work "History of World Medicine". But due to the lack of proper care and supervision by the authorities, the polyptych was destroyed.

Unfortunately, there are many examples of such indifference and acts of vandalism. Thus, the reliefs of N.F. Barokha on Engels Street in Volzhsky needs to be repaired. The mosaic bas-relief "Rose of the Winds" near the tourist station of Volgograd by M.Ya. Pyshta is completely lost. While repairing Fischer hospital the unique mosaic "People in White Coats" by G.V. Chernoskutov was destroyed. Mosaic on the building of the former Aurora factory by G.M. Vyatkin was immured behind the new facade. The mosaic of P.I. Chaplygin "Dove of Peace" in the underpass in Mira Street was covered with paint ("Figure 5") 


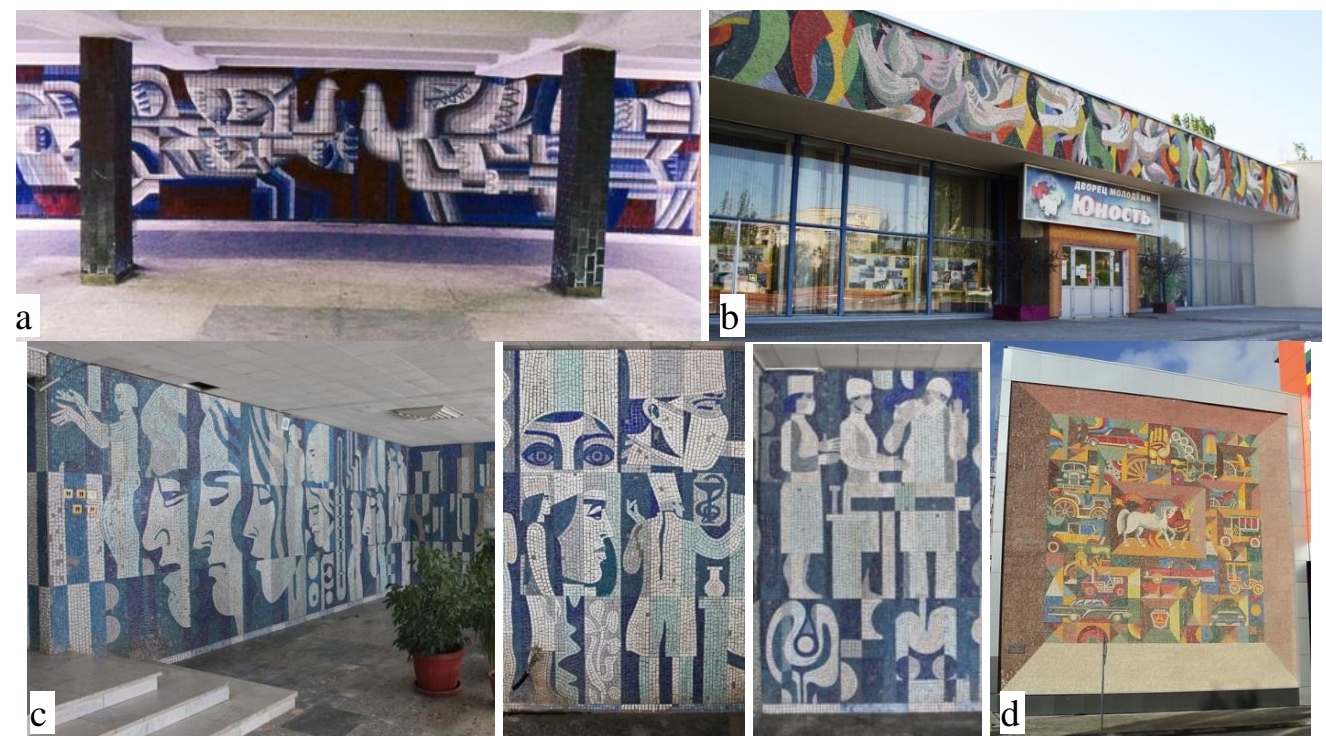

Figure 5 a. "Dove of peace". Underground pass. Volgograd, 1990, author P.I. Chaplygin; b. "Doves". Cinema "Youth". Volzhsky, 1985, c. "People in white coats." Hospital them. S.Z. Fisher. Volzhsky, 1977, d. "The history of the development of motor transport." Volzhsky, 1994, author G.V. Chernoskutov.

However, there are cases of well-preserved mosaics. We are talking about the mosaic "The history of the Development of Motor Transport" in Volzhsky. While reconstructing the Planeta Leto shopping center, the mosaic by G.V. Chernoskutov decorating the part of the old building of the taxi company was integrated into the new complex. churches began. They started to be decorated with stained-glass windows, paintings, mosaics. Mosaics are located on the facades of the Church of St. Sergius of Radonezh and on the restored chapel of the Alexander Nevsky Cathedral in Volgograd, as well as on the Cathedral Church of St. John the Theologian in Volzhsky ("Figure 6").

After the collapse of the USSR in 1991 and atheism as a state ideology, active construction of

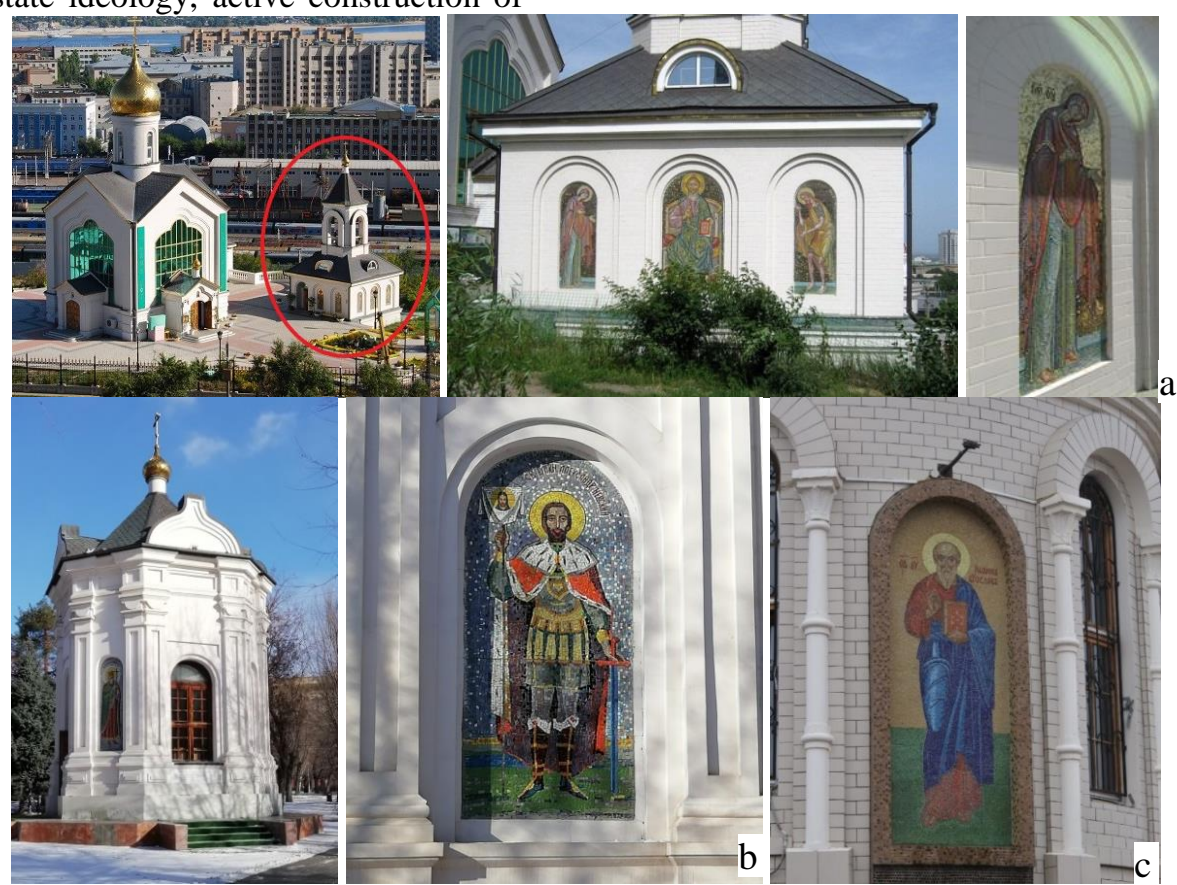

Figure 6 a. baptismal church of St. Sergius of Radonezh, 2002, authors: P.F. Shardakov, A.G. Brovko; b. chapel of the Alexander Nevsky Cathedral. Volgograd, 2005, authors from Rostov-on-Don; c. cathedral church of St. John the Evangelist. Volzhsky, 2015, author V.A. Osmikin. 


\section{CONCLUSION}

All that was discussed above is an attempt to generalize observations on the collected and studied material, to emphasize the existing threats and risks to the vast and valuable heritage of one of the important elements of monumental art (mosaics) of Volgograd and Volzhsky.

Analysis of mosaics on the facades of public and residential buildings in Volgograd and Volzhsky allows us to draw the following conclusions:

- The history of monumental painting in the urban environment of Volgograd and Volzhsky is marked by achievements in some periods and decline in others;

- Despite the fact that in general the monumental art of Volgograd and Volzhsky is saturated with socialist ideology and military-historical themes, the monumental painting of cities bears the themes of creation, development and peace;

- Mosaics are elements of the synthesis of architecture and monumental art of Volgograd and Volzhsky and play a key role in forming and harmonizing the urban environment;

- Many city mosaics are lost or significantly damaged. Therefore, it is important to study and preserve monumental art and carry out urgent restoration work where necessary.

\section{AUTHORS' CONTRIBUTIONS}

V. Serebryanaya developed the concept of the study and analyzed the sources. The regional features and the place of mosaics in creating an integral architectural ensemble of the city have been determined. I. Shevchuk revealed existing and lost mosaics on the territory of Volgograd and Volzhsky, photo fixing was made.

\section{REFERENCES}

[1] D.S. Likhachev, Notes about Russian (Zametki o russkom). Moscow: Sov. Russia, 1981, 71 p. [in Russian].

[2] V. I. Atopov, V. E. Maslyaev, A. F. Lipyavkin, Volgograd (Volgograd). Moscow: Stroyizdat, 1985, 216 p. [in Russian].

[3] P.P. Oleinikov, From the Past to the Future. Architecture of Tsaritsyn, Stalingrad,
Volgograd (Iz proshlogo - v budushhee. Arxitektura Czaricyna, Stalingrada, Volgograda). Volgograd, 2017, 184 p. [in Russian].

[4] S.S. Valerius, Monumental Painting: Contemporary Problems (Monumental'naya zhivopis': Sovremennye problemy). Moscow: Art, 1979, 87 p. [in Russian].

[5] V.P. Tolstoy, Soviet monumental painting (Sovetskaya monumental'naya zhivopis`). Moscow, 1958, 304 p. [in Russian].

[6] O.A. Shvidkovsky, Harmony of interaction: Architecture and monumental art (Garmoniya vzaimodejstviya: Arxitektura i monumental noe iskusstvo). Moscow: Stroyizdat, 1984, 280 p. [in Russian].

[7] E.B. Murina, Problems of synthesis of spatial arts (Problemy sinteza prostranstvennyh iskusstv). Moscow: Art, 1982, 192 p. [in Russian].

[8] A.Ph. Lagopoulos, Monumental urban space and national identity: the early twentieth century new plan of Thessaloniki, Journal of Historical Geography, vol. 31, issue 1, 2005, pp. 61-77.

[9] G. Mitrache, Architecture, Art, Public Space, Procedia - Social and Behavioral Sciences, vol. 51, 2012, pp. 562-566.

[10] Volgograd artist: Album (Volgogradskij xudozhnik: Al’bom). Volgograd, 1994, 216 p. [in Russian].

[11] Volgograd artist: Album (Volgogradskij xudozhnik: Al’bom). Volgograd, 2007, 208 p. [in Russian].

[12] Decrees of the Soviet government. Volume II. March 17 - July 10 (Dekrety` Sovetskoj vlasti. Tom II. 17 marta - 10 iyulya 1918 g.). Moscow: Gospolitizdat, 1959 [in Russian].

[13] On the elimination of excesses in design and construction: Resolution Center. Com. The CPSU and the Council of Ministers of the USSR on November 4, 1955 (Ob ustranenii izlishestv $\mathrm{V}$ proektirovanii i stroitel stve: Postanovlenie Centr. Kom. KPSS i Soveta Ministrov SSSR 4 noyabrya 1955 g.). Moscow: Gospolitizdat, 1955, 14 p. [in Russian].

[14] I.R. Grigulevich, Siqueiros (Sikejros). Moscow: Art, 1980, 248 p. [in Russian].

[15] L.A. Zhadova, Fernand Leger (Fernan Lezhe). Moscow: Art, 1970, 142 p. [in Russian]. 